\title{
Group Decision Support System (GDSS) Untuk Evaluasi Penawaran Pekerjaan Konstruksi Menggunakan Metode AHP dan Borda
}

\author{
Gede Ogiana ${ }^{1}$, Ni Made Ary Esta Dewi Wirastuti ${ }^{2}$, Wayan Gede Ariastina ${ }^{3}$
}

\begin{abstract}
Evaluation of bids by WG ULP has an important role in the selection of providers of construction work to determine the potential winner. A group decision support system is a system that can help the Working Group ULP Bali provincial government in making decisions with the ability to analyze the construction work provider selection criteria with AHP and Borda method. With GDSS bid evaluation, all members of the Working Group can evaluate the ULP provider offering construction work optimally based on the criteria of administrative, technical prices so as to improve the quality of the repair process of group decision-making. Both methods are used because there are two stages in the decision-making that decision of individual and group decision. The test results show that the system can be applied GDSS as decision support systems in the bid evaluation provider of construction work and decided the company's most worthy to be a winner.
\end{abstract}

Intisari- Evaluasi penawaran oleh Pokja ULP memiliki peran penting dalam pemilihan penyedia pekerjaan konstruksi untuk menentukan calon pemenang. Sistem pendukung keputusan kelompok merupakan suatu sistem yang dapat membantu Kelompok Kerja ULP Pemerintah Provinsi Bali dalam mengambil keputusan dengan kemampuan analisa pemilihan penyedia pekerjaan konstruksi dengan metode kriteria AHP dan Borda. Dengan GDSS evaluasi penawaran, semua anggota Pokja ULP dapat melakukan evaluasi penawaran penyedia pekerjaan konstruksi secara optimal berdasarkan kriteria administrasi, teknis harga sehingga dapat meningkatkan kualitas dalam perbaikan proses pengambilan keputusan kelompok. Kedua metode tersebut digunakan karena terdapat dua tahap dalam pengambilan keputusan yaitu individual decision dan group decision. Hasil pengujian sistem menunjukkan bahwa GDSS dapat diterapkan sebagai sistem pendukung keputusan dalam evaluasi penawaran penyedia pekerjaan konstruksi dan memutuskan perusahaan yang paling layak untuk menjadi pemenang.

Kata Kunci- GDSS, AHP, Borda, Evaluasi Penawaran.

\section{Pendahuluan}

Saat ini proses pemilihan penyedia pekerjaan konstruksi pada ULP Pemerintah Provinsi Bali telah dilaksanakan secara elektronik melalui Layanan Pengadaan Secara Elektronik

\footnotetext{
${ }^{1}$ Mahasiswa, Program Studi Magister Teknik Elektro, Jalan Batu Intan IIIA Blok 3 No.2 Batubulan, Sukawati, Gianyar Bali Indonesia (tlp: 0361-239599; fax: 0361-239599; e-mail: gedeogiana@gmail.com)

2, 3 Dosen, Program Studi Magister Teknik Elektro, Jalan Panglima Besar Sudirman, Denpasar Bali Indonesia (tlp: 0361239599; fax: 0361-239599; e-mail: arydev_02@yahoo.com, w_ariastina@yahoo.com)
}

Gede Ogiana: Group Decision Support System (GDSS)...
(LPSE). Penerapan aplikasi LPSE ini sangat membantu Pokja ULP dalam meningkatkan kinerja pelayanan, memberikan informasi secara real time dan mewujudkan clean and good government [1]. Namun disisi lain, yang menjadi kendala utama dalam proses pemilihan tersebut adalah tahap evaluasi penawaran dimana masih bersifat offline diluar LPSE dan tidak dilakukan secara terkomputerisasi dengan perangkat lunak. Evaluasi penawaran yang dilakukan masih bersifat individu dalam satu komputer oleh satu anggota Pokja ULP dan hal ini terkesan bukan merupakan keputusan kelompok.

Kondisi ini tentunya menyebabkan kurang efisiennya waktu dalam pencarian data lelang dan kesulitan dalam menggabungkan hasil evaluasi masing-masing anggota Pokja ULP menjadi satu keputusan kelompok mengingat sesuai tugas dan kewenangan ULP [2], Pokja ULP harus melakukan pemilihan penyedia pekerjaan konstruksi secara berkelompok dan mendukung terwujudnya layanan pengadaan barang dan jasa yang efektif dan efesien [3].

Salah satu solusi untuk mengatasi fenomena tersebut adalah penerapan Group Decision Support System (GDSS). Beberapa hasil penelitian GDSS sebelumnya menunjukkan sistem pendukung keputusan untuk pemilihan tanaman kering menggunakan metode Nearest neighbor dapat menghasilkan urutan prioritas perangkingan tanaman dan metode Borda digunakan untuk penggabungan penilaian beberapa instansi selaku decision maker, sehingga dapat membantu para pengambil keputusan untuk mendapatkan keputusan terbaik. [4]. GDSS dengan metode Brow-Gibson dan Borda dalam penentuan lokasi shelter dapat mengakomodasi preferensi dari banyak pembuat keputusan dan memudahkan para pengambil keputusan menentukan pilihan lokasi terbaik [5]. Sementara GDSS dengan metode VIKOR (Vlse Kriterijumska Optimizacija Kompromisno Resenje in Serbia) dapat membantu decision maker dalam melakukan perankingan nilai masing-masing alternatif solusi, sedangkan entropy sebagai pembobotannya dari setiap kriteria [6].

Berdasarkan permasalahan tersebut, maka dalam penelitian ini akan dirancang model GDSS menggunakan metode AHP dan Borda untuk evaluasi penawaran pekerjaan konstruksi. Dipilihnya metode AHP, karena metode ini digunakan untuk mendukung individual decision dalam evaluasi penawaran dan dapat menentukan pemenang terbaik dari hasil penilaian yang ada [7]. Dengan melihat kriteria evaluasi penawaran yang dipergunakan untuk penentuan pemenang, menggunakan metode AHP sangat cocok karena sesuai dengan ketentuan dan peraturan pengadaan barang dan jasa pemerintah. Sedangkan Borda digunakan untuk menggabungkan nilai masing-masing decison maker dan menentukan calon pemenang terbaik dari beberapa penyedia yang lulus penilaian dengan metode AHP [8].

$$
\text { p-ISSN:1693 - 2951; e-ISSN: 2503-2372 }
$$

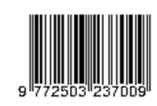




\section{GDSS Evaluasi PENAWARAN}

GDSS Evaluasi penawaran pekerjaan konstruksi merupakan kegiatan Pokja ULP dalam menilai semua dokumen penawaran yang diunggah pada LPSE oleh perusahaan yang ikut serta dalam pelelangan suatu paket pekerjaan konstruksi berdasarkan metode AHP dan Borda .

\section{A. Evaluasi Penawaran}

Evaluasi penawaran memiliki peran penting dalam pemilihan penyedia konstruksi karena hasil penilaian tersebut dijadikan dasar untuk memilih penyedia yang layak dan terbaik untuk melaksanakan pekerjaan konstruksi berdasarkan persyaratan yang ditetapkan dalam dokumen pengadaan [9].

1) Evaluasi Administrasi : Evaluasi terhadap data penawaran administrasi penyedia yang dicocokkan dengan syarat-syarat administrasi yang tertulis dalam dokumen pengadaan [2][10].

2) Evaluasi Teknis: Lanjutan proses penilaian setelah evaluasi administrasi, yang merupakan evaluasi terhadap data penawaran teknis penyedia yang dicocokan dengan syaratsyarat teknis dan diberi nilai sesuai kriteria evaluasi teknis [2][10].

3) Evaluasi Harga: merupakan evaluasi kewajaran harga penawaran yang dibandingkan dengan persyaratan Harga Perkiraan Sendiri (HPS) dan Analisa Harga Satuan Pekerjaan (AHSP) serta syarat evaluasi harga lainnya sesuai kriteria evaluasi harga [2][10].

\section{B. Pokja ULP}

Proses pemilihan penyedia konstruksi khususnya evaluasi penawaran dilaksanakan oleh Kelompok Kerja (Pokja) Unit Layanan Pengadaan (ULP). Menurut Perka LKPP No. 5 Tahun 2012 pasal 1 poin 8 : "Kelompok Kerja ULP selanjutnya disebut Pokja ULP adalah kelompok kerja yang berjumlah gasal, beranggotakan paling kurang 3 (tiga) orang dan dapat ditambah sesuai dengan kompleksitas pekerjaan, yang bertugas untuk melaksanakan pemilihan penyedia pengadaan barang/jasa di Kementerian/Lembaga/Pemerintah Daerah/Institusi”.

\section{METODE PENELITIAN}

\section{A. Alur Penelitian}

Tahapan penelitian yang digunakan dalam sistem pendukung keputusan kelompok ini , yaitu:

1. Identifikasi dan merumuskan masalah, menetapkan batasan, tujuan dan manfaat penelitian GDSS.

2. Studi kepustakaan kajian teoritis dan penelitian sebelumnya yang berkaitan dengan keaslian penelitian GDSS menggunakan metode AHP dan Borda.

3. Analisa kebutuhan dan pemodelan sistem berdasarkan pemahaman terhadap proses-proses evaluasi penawaran

4. Perancangan sistem aplikasi pendukung keputusan berupa rancangan database dan interface GDSS.

5. Pembangunan dan pemrograman aplikasi GDSS.

6. Implementasi dan pengujian GDSS evaluasi penawaran pada Pokja ULP Pemerintah Provinsi Bali.

7. Pembuatan laporan penelitian.

\section{B. Proses Evaluasi Penawaran Dengan Metode AHP}

Untuk menentukan lulus atau tidaknya penyedia konstruksi dalam mengajukan penawaran pada proses pemilihan penyedia pekerjaan konstruksi dengan metode AHP terdapat 3 (tiga) kriteria yang harus dipenuhi yaitu administrasi, teknis dan harga.

Langkah metode AHP yang harus dilakukan dalam menentukan prioritas kriteria adalah sebagai berikut [11] :

1. Mendefenisikan permasalahan sistem evaluasi penawaran pekerjaan konstruksi dan menentukan tujuan utama atau goal yang diinginkan.

2. Menetapkan prioritas kriteria dengan membuat beberapa matriks dan mengecek rasio konsistensi semua kriteria evaluasi penawaran.

3. Menentukan dan menghitung prioritas subkriteria. Matriks hasil AHP berupa kriteria evaluasi terdiri dari administrasi, teknis dan harga. Sedangkan subkriteria yang merupakan rentang nilai kriteria evaluasi dapat dilihat pada Tabel I.

TABEL I

MATRIKS HASIL PRIORITAS KRITERIA DAN SUBKRETERIA

\begin{tabular}{|c|c|c|}
\hline Administrasi $(\boldsymbol{A})$ & Teknis $(\boldsymbol{T})$ & Harga $(\boldsymbol{H})$ \\
\hline 0,42 & 0,21 & 0,10 \\
\hline Sangat Cocok & Sangat Cocok & Sangat Cocok \\
\hline 1 & 1 & 1 \\
\hline Sedikit Lebih Cocok & Sedikit Lebih Cocok & Sedikit Lebih Cocok \\
\hline 0,65 & 0,65 & 0,65 \\
\hline Cocok & Cocok & Cocok \\
\hline 0,39 & 0,39 & 0,39 \\
\hline Kurang Cocok & Kurang Cocok & Kurang Cocok \\
\hline 0,24 & 0,24 & 0,24 \\
\hline Sangat Tidak Cocok & Sangat Tidak Cocok & Sangat Tidak Cocok \\
\hline 0,14 & 0,14 & 0,14 \\
\hline
\end{tabular}

Sesuai Tabel I, nilai prioritas kriteria yaitu adminitrasi $=$ 0,42 , teknis $=0,21$ dan harga $=0,10$. Sedangkan nilai subkriteria prioritas ada 5 yaitu sangat cocok (1), sedikit lebih cocok $(0,65)$, cocok $(0,39)$, kurang cocok $(0,24)$, dan sangat tidak cocok $(0,14)$.

Berdasarkan matriks hasil perhitungan AHP pada Tabel 1, selanjutnya digunakan untuk menilai peserta lelang pemilihan penyedia konstruksi yang memasukkan penawaran dalam satu paket lelang. Misalkan dalam satu paket pekerjaan konstruksi yang dilelang, dilakukan evaluasi penawaran dan pemberian nilai sesuai kriteria dan subkriteria Tabel 1 oleh salah satu anggota Pokja ULP terhadap 4 dokumen penawaran peserta penyedia konstruksi (PK). Penilaian dengan metode AHP oleh salah satu anggota dapat dilihat pada Tabel 2 .

TABEL II

Penilaian Dokumen Oleh Satu AngGota PoKJa

\begin{tabular}{|c|c|c|c|}
\hline \multirow{2}{*}{ Perusahaan } & \multicolumn{3}{|c|}{ Katagori } \\
\cline { 2 - 4 } & Adm & Teknis & Harga \\
\hline PK1 & Sangat Cocok & $\begin{array}{c}\text { Sangat Tidak } \\
\text { Cocok }\end{array}$ & $\begin{array}{c}\text { Sangat Tidak } \\
\text { Cocok }\end{array}$ \\
\hline PK2 & Kurang Cocok & Sedikit Lebih & Cocok \\
\hline
\end{tabular}




\begin{tabular}{|c|c|c|c|}
\hline \multirow{2}{*}{ Perusahaan } & \multicolumn{3}{|c|}{ Katagori } \\
\cline { 2 - 4 } & Adm & Teknis & Harga \\
\hline & & Cocok & \\
\hline PK3 & Sangat Cocok & Cocok & Sangat Cocok \\
\hline PK4 & Kurang Cocok & $\begin{array}{c}\text { Sangat Tidak } \\
\text { Cocok }\end{array}$ & $\begin{array}{c}\text { Sedikit Lebih } \\
\text { Cocok }\end{array}$ \\
\hline
\end{tabular}

Berdasarkan penilaian salah satu anggota Pokja dengan metode AHP seperti Tabel 2, dilakukan konversi sesuai dengan subkriteria pada Tabel 1. Hasil penyesuaian nilai tersebut dituangkan pada Tabel 3 .

TABEL III

Hasil Penilaian AHP Oleh Satu ANgGota PokJa UlP

\begin{tabular}{|c|c|c|c|c|c|}
\hline \multirow{2}{*}{ Perusahaan } & \multicolumn{3}{|c|}{ Katagori } & \multirow{2}{*}{ Total } & \multirow{2}{*}{ Peringkat } \\
\cline { 2 - 4 } & Adm & Teknis & Harga & & \\
\hline PK1 & 0,42 & 0,08 & 0,01 & 0,51 & 2 \\
\hline PK2 & 0,10 & 0,13 & 0,03 & 0,26 & 3 \\
\hline PK3 & 0,42 & 0,08 & 0,10 & $0, .60$ & 1 \\
\hline PK4 & 0,10 & 0,02 & 0,06 & 0,18 & 4 \\
\hline
\end{tabular}

Pada Tabel 3, nilai 0,42 pada kolom administrasi dan baris perusahaan PK1 diperoleh dari nilai administrasi perusahaan PK1 yaitu sangat cocok dengan prioritas 1 dikalikan dengan prioritas administrasi 0,42. Begitu juga dengan dua kolom katagori lainnya (teknis dan harga) dan baris perusahaan lainnya (PK2, PK3 dan PK4) diberikan nilai sesuai kriteria dan subkriteria Tabel 1. Semakin cocok dokumen penawaran yang diajukan, semakin tinggi nilai yang diperoleh. Nilai ketiga katagori tersebut dijumlahkan sehingga diperoleh total nilai dan selanjutnya ditentukan peringkat dari keempat peserta. Semakin tinggi total nilai semakin besar peluang dipilih sebagai pemenang lelang. Penyedia konstruksi yang memperoleh nilai terbesar adalah pemenang. Pada Tabel 3 pemenang atau peringkat pertama oleh salah satu anggota Pokja ULP adalah PK3 dengan total nilai 0,60.

\section{Proses Evaluasi Penawaran Dengan Metode Borda}

Dengan metode AHP, setiap anggota kelompok kerja bisa melakukan penilaian terhadap dokumen penawaran penyedia kontruksi yang memasukkan penawaran. Dimana hasil penilaiannya diperoleh total nilai yang dijadikan dasar menentukan peringkat dari keempat peserta penyedia konstruksi. Namun dalam hal hanya satu peserta yang memasukkan penawaran, proses evaluasi dengan metode Borda tidak dilakukan karena tidak ada penyedia kontruksi yang dipilih dan diperingkat. Hasil evaluasi 7 anggota Pokja ULP selaku decision maker dituangkan dalam Tabel 4.

TABEL IV

Hasil Penilaian OLEH 7 ANGgota PoKJa ULP

\begin{tabular}{|c|c|c|c|c|c|c|c|}
\hline \multirow{2}{*}{ Perusahaan } & \multicolumn{7}{|c|}{ Peringkat } \\
\cline { 2 - 8 } & DM1 & DM2 & DM3 & DM4 & DM5 & DM6 & DM7 \\
\hline PK1 & 2 & 3 & 3 & 2 & 2 & 3 & 2 \\
\hline PK2 & 3 & 1 & 2 & 3 & 3 & 2 & 3 \\
\hline PK3 & 1 & 2 & 1 & 1 & 1 & 1 & 1 \\
\hline
\end{tabular}

Gede Ogiana: Group Decision Support System (GDSS)...

\begin{tabular}{|c|c|c|c|c|c|c|c|}
\hline \multirow{2}{*}{ Perusahaan } & \multicolumn{7}{|c|}{ Peringkat } \\
\cline { 2 - 8 } & DM1 & DM2 & DM3 & DM4 & DM5 & DM6 & DM7 \\
\hline PK4 & 4 & 4 & 4 & 4 & 4 & 4 & 4 \\
\hline
\end{tabular}

Untuk menggabungkan hasil penilaian masing-masing anggota Pokja ULP berdasarkan hasil penilaian Tabel 4, selanjutnya digunakan metode pengambilan keputusan dengan metode Borda.

Proses evaluasi penawaran dengan metode Borda dilakukan dengan tahapan sebagai berikut :

1. Bobot peringkat Borda dapat dihitung dengan memberikan masing-masing peserta penyedia konstruksi sejumlah poin sesuai dengan banyaknya peserta yang lulus evaluasi penawaran. Jika terdapat $\mathrm{n}$ penyedia konstruksi untuk diranking, pilihan pertama berbobot $\mathrm{n}-1$, pilihan kedua berbobot $n-2$, dan seterusnya sampai pada pilihan ke-n akan berbobot 0 .

Dalam hal ini hasil perhitungan AHP ada 4 perusahaan yang dievaluasi dan dirangking $(n=4)$, sehingga untuk pilihan pertama berbobot 3 , pilihan kedua berbobot 2 dan seterusnya, serta poin 0 diberikan untuk peringkat yang terakhir.

2. Kemudian dilakukan penggabungan atau penjumlahan hasil peringkat AHP yang sama dari 7 anggota Pokja sebagaimana Tabel 4.

3. Total nilai Borda dari masing-masing penyedia konstruksi diperoleh dengan menjumlahkan hasil kali jumlah peringkat AHP pada posisi atau peringkat yang sama dengan bobot peringkat Borda. Perkalian dan penjumlahan tersebut dihitung dengan cara sebagai berikut :

$$
\begin{aligned}
& \text { PK1 }=(0 \times 3)+(4 \times 2)+(3 \times 1)+(0 \times 0)=11 \\
& \text { PK2 }=(1 \times 3)+(1 \times 2)+(4 \times 1)+(0 \times 0)=9 \\
& \text { PK3 }=(6 \times 3)+(1 \times 2)+(0 \times 1)+(0 \times 0)=20 \\
& \text { PK4 }=(0 \times 3)+(0 \times 2)+(0 \times 1)+(7 \times 0)=0
\end{aligned}
$$

Matriks hasil evaluasi penawaran dan peringkat dengan

\begin{tabular}{|c|c|c|c|c|c|c|}
\hline \multirow{2}{*}{ Perusahaan } & \multicolumn{4}{|c|}{ Hasil Peringkat AHP } & \multirow{2}{*}{ Total } & \multirow{2}{*}{ Peringkat } \\
\hline & 1 & 2 & 3 & 4 & & \\
\hline PK1 & & 4 & 3 & & 11 & 2 \\
\hline PK2 & 1 & 2 & 4 & & 9 & 3 \\
\hline PK3 & 6 & 1 & & & 20 & 1 \\
\hline PK4 & & & & 7 & 0 & 4 \\
\hline $\begin{array}{c}\text { Bobot } \\
\text { Peringkat }\end{array}$ & 3 & 2 & 1 & 0 & & \\
\hline
\end{tabular}
metode Borda dapat dilihat pada Tabel 5.

TABEL V

Hasil Evalusi Penawaran Dengan Metode Borda

Sesuai dengan Tabel 5 dapat diketahui total nilai dan peringkat metode Borda yang diperoleh oleh keempat perusahaan. Penyedia konstruksi yang memperoleh nilai hasil penggabungan terbesar adalah sebagai pemenang. Pemenang atau peringkat pertama berdasarkan penilaian ketujuh anggota Pokja ULP adalah PK3 dengan total nilai 20.

\section{Perancangan GDSS}

Berdasarkan pengamatan dan analisa kebutuhan sistem evaluasi penawaran penyedia pekerjaan kontruksi, maka

p-ISSN:1693 - 2951; e-ISSN: 2503-2372 
dirancang suatu sistem berbasis teknologi informasi yang mendukung pertemuan kelompok kerja dalam menyelesaikan tugas atau tujuan yang sama [3]. GDSS mendukung aktivitas kelompok kerja, termasuk kegiatan Pokja ULP Pemerintah Provinsi Bali dalam melakukan evaluasi penawaran secara pararel dengan interface aplikasi yang sama. GDSS evaluasi penawaran dengan metode AHP dan Borda ini dibangun dengan bahasa pemrograman PHP framework dan database sistem pendukung keputusan kelompok yang digunakan adalah MySQL. Rancangan GDSS evaluasi penawaran dapat dilihat pada Gambar 1.

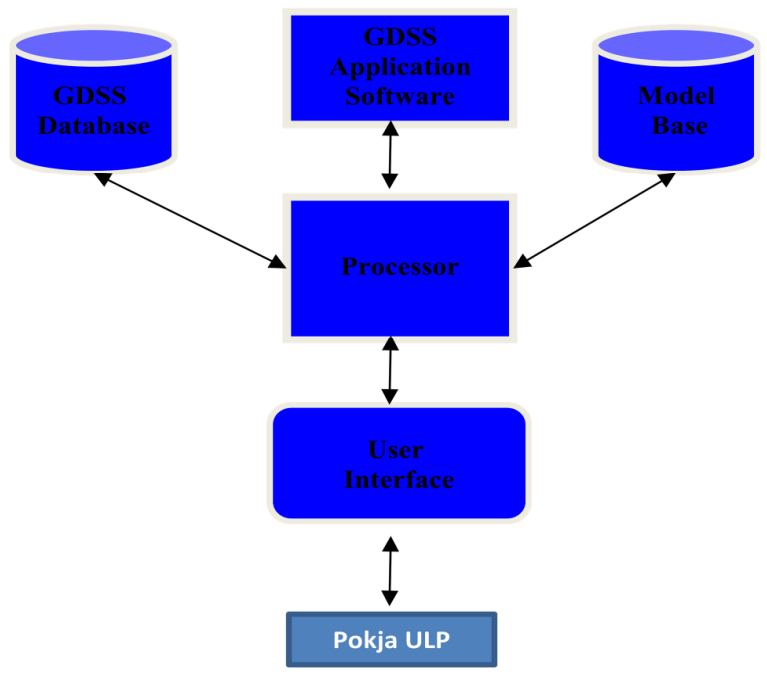

Gambar 1: Rancangan GDSS evaluasi penawaran

\section{HASIL DAN PEMBAHASAN}

\section{A. Interface GDSS Pokja}

Hasil dari penelitian ini adalah sebuah aplikasi sistem penunjang keputusan Pokja ULP untuk evaluasi penawaran penyedia konstruksi menggunakan metode AHP dan Borda . Dalam proses evaluasi penawaran dengan sistem ini, Pokja ULP terlebih melakukan proses login sesuai user id dan password masing-masing anggota Pokja ULP yang mempunyai tugas dan wewenang melakukan evaluasi penawaran paket pekerjaan konstruksi yang dilelang di ULP Pemerintah Provinsi Bali.

Sebelum melakukan proses evaluasi Ketua Pokja ULP atau salah satu anggota Pokja memasukkan data anggota Pokja ULP yang melakukan proses penilaian secara berkelompok untuk pengambilan keputusan evaluasi penawaran. Dalam hal ini Pokja ULP yang terdaftar dan memiliki hak akses pada sistem ini adalah sebanyak 7 (tujuh) orang termasuk 1 (satu) orang ketua merangkap anggota. Karena tampilan halaman data master sistem ini sama untuk ketujuh Pokja, maka salah satu anggota Pokja ULP dapat mengolah data master seperti data Pokja, data SKPD, data penyedia dan data peket pekerjaan. Gambar 2 dibawah ini merupakan tampilan form data Pokja ULP.

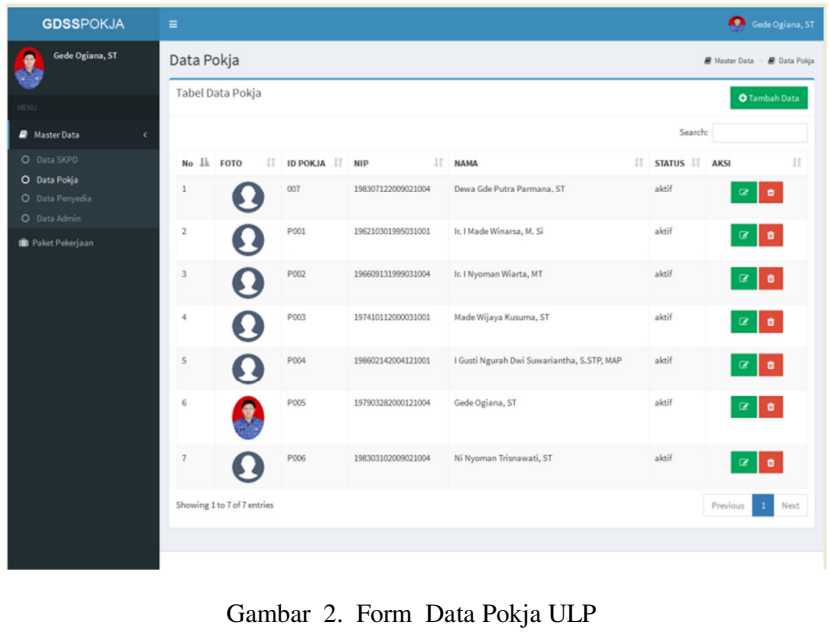

Selanjutnya untuk tahap kedua, pada Gambar 3 merupakan tampilan halaman Pokja untuk mengolah data Satuan Kerja Perangkat Daerah (SKPD) atau instansi Pemerintah Provinsi Bali yang mempunyai kegiatan paket pekerjaan konstruksi pada suatu tahun anggaran. Data ini digunakan sebagai referensi untuk input data paket pekerjaan yang sudah dilelang.

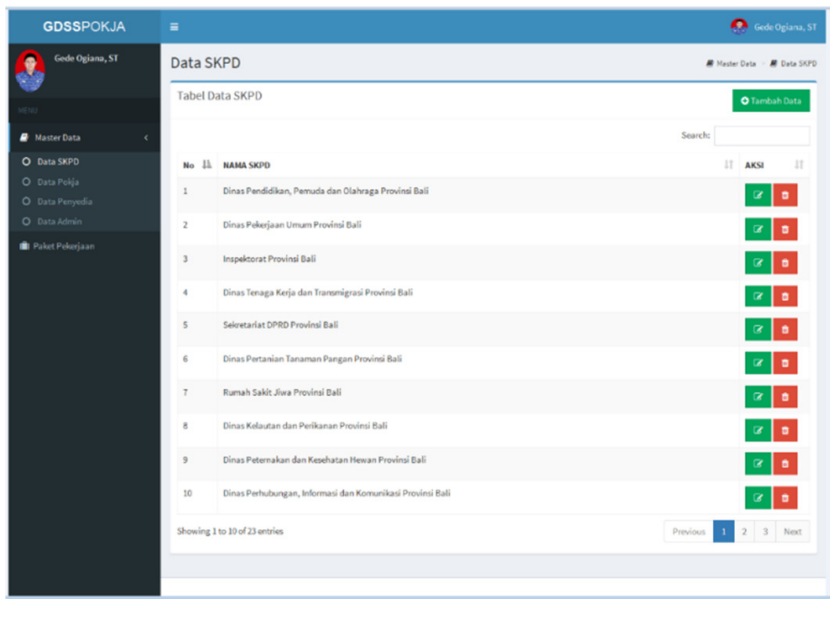

Gambar 3. Input Data SKPD

Data penyedia merupakan implementasi dari pengolahan data penyedia yang mengikuti pelelangan umum atau pemilihan langsung penyedia pekerjaan konstruksi pada LPSE Provinsi Bali. Sebagaimana pada Gambar 4, menu ini digunakan untuk mengolah data kualifikasi penyedia pekerjaan konstruksi yang telah terdaftar dan memasukkan penawaran di aplikasi LPSE. Untuk penggunaan fitur ini, Pokja ULP dapat menambahkan referensi data penyedia yang ikut pelelangan yang belum terdapat di data penyedia. Dengan telah tersimpannya data penyedia ini, pencarian data informasi penyedia yang menawar pada halaman evaluasi dapat dilakukan dengan cepat tanpa harus mengetik lagi. 


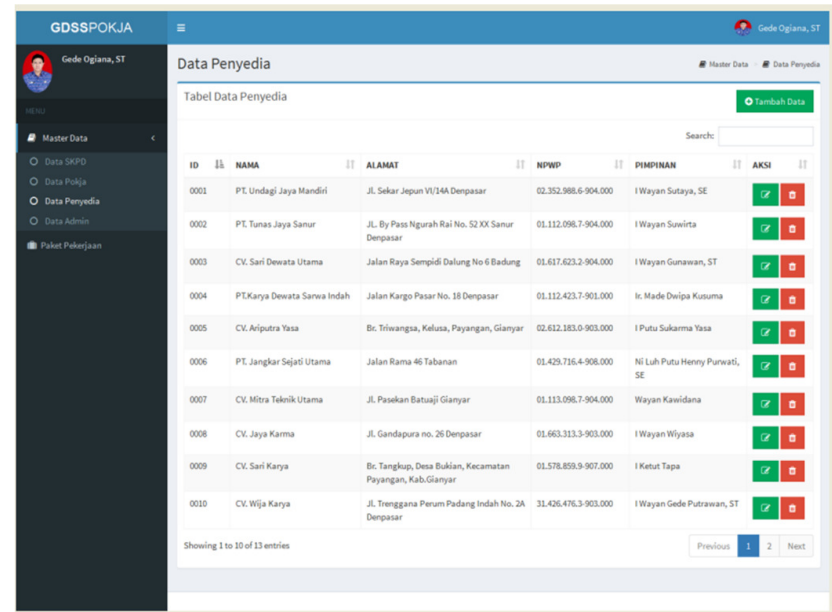

Gambar 4: Form Data Penyedia.

\section{B. Proses Evaluasi Penawaran}

Proses evaluasi penawaran berbasis work grouping adalah proses dimana Pokja ULP melakukan tiga tahapan evaluasi yaitu evaluasi administrasi, teknis dan harga. Sebelum melakukan proses evaluasi Pokja ULP harus menginput detail rincian paket pekerjaan konstruksi sesuai data lelang pada LPSE. Dalam hal ini, data paket pekerjaan konstruksi yang digunakan sebagai data uji coba system adalah data peket pekerjaa tahun anggaran 2015 yang dilelang pada sistem pengadaan secara elektronik LPSE Provinsi Bali. Data paket tersebut telah dilakukan evaluasi penawaran dengan sistem gugur.

Setelah mengunduh dan membuka dokumen penawaran sesuai paket pekerjaan konstruksi yang dilelang pada Sistem Pengadaan Secara Elektronik (SPSE), anggota pokja ULP mengevaluasi dokumen tersebut menggunakan metode AHP pada aplikasi GDSS Evaluasi Penawaran. Pokja ULP dapat menambahkan dan mengolah data paket pekerjaan pada form sebagaimana Gambar 5 dan Gambar 6 .

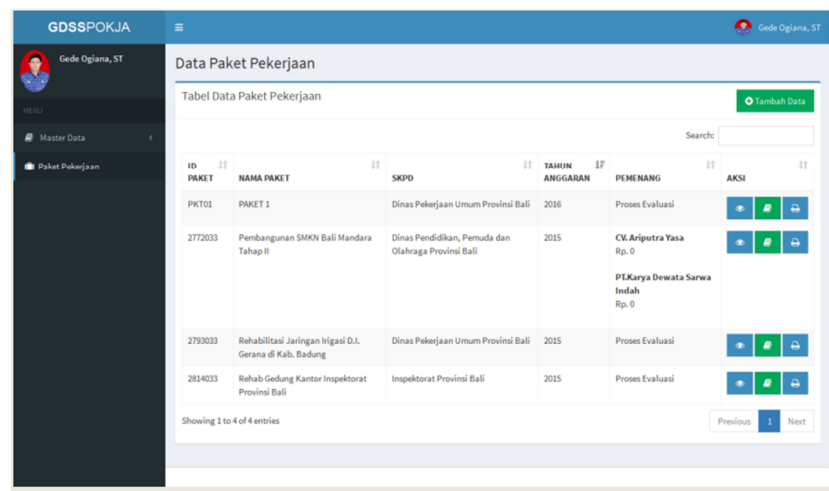

Gambar 5. Form Input Data Paket Pekerjaan

Gede Ogiana: Group Decision Support System (GDSS)...

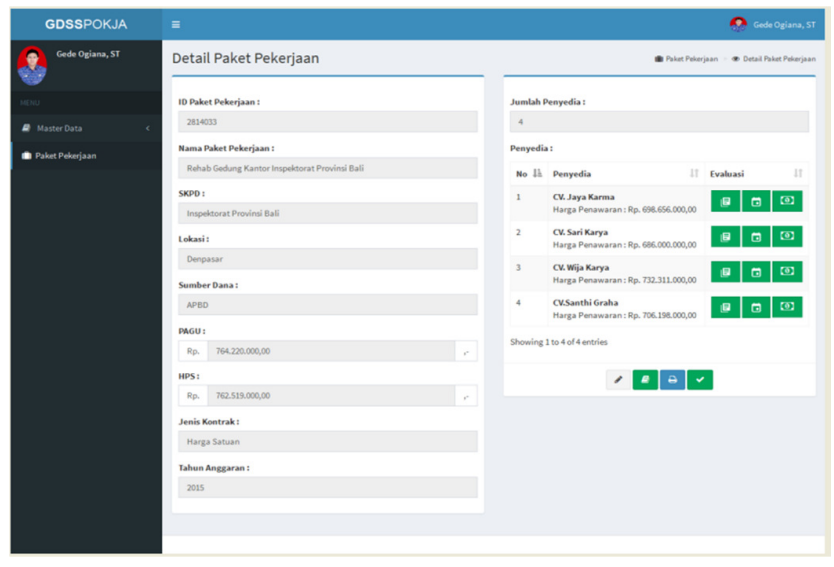

Gambar 6. Form Detail Paket Pekerjaan

Berikut akan dijelaskan proses evaluasi penawaran menggunakan aplikasi GDSS.

1. Evaluasi Administrasi Metode AHP

Setelah data paket pekerjaan beserta rinciannya diinput, maka Pokja ULP selanjutnya melakukan evaluasi sesuai kriteria dan subkriteria pada Tabel I. Evaluasi administrasi merupakan evaluasi awal yang dilakukan terhadap dokumen penawaran katagori administrasi seperti surat penawaran, daftar kuantitas harga, surat dukungan bank, surat pernyataan dan syarat administrasi lainnya. Pokja ULP memberikan nilai kecocokan dengan cara meneliti dokumen penawaran administrasi dan membadingkan dengan persyaratan dalam dokumen pengadaan. Gambar 7 dibawah ini merupakan menu untuk Pokja memilih atau mencentang sesuai 5 subkriteria AHP.

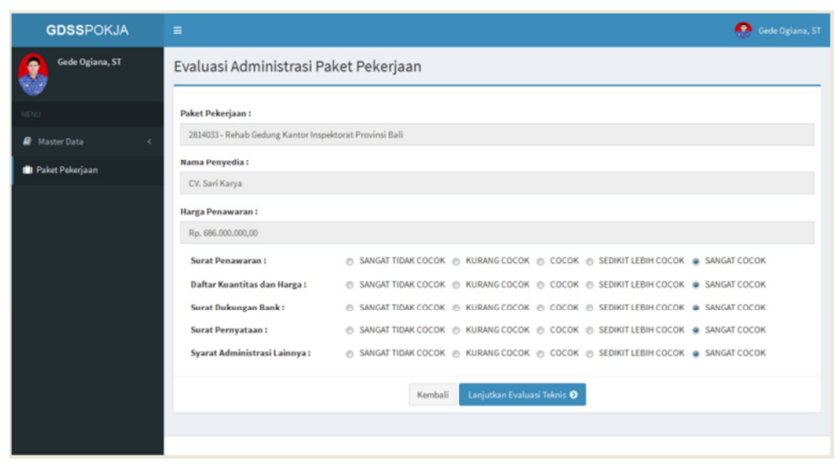

Gambar 7. Form Evaluasi Administrasi

2. Evaluasi Teknis Metode AHP

Proses penilaian dokumen penawaran teknis dilakukan terhadap perusahaan yang sudah dievaluasi administrasi. Dokumen penawaran teknis penyedia diberi nilai sesuai subkriteria teknis pada Tabel 1. Pokja ULP memberikan nilai kecocokan sesuai dokumen teknis yang dipersyaratkan dalam dokumen pengadaan seperti metode pelaksanaan, jangka waktu pelaksanaan, spesifikasi teknis, personil inti, peralatan utama dan syarat teknis lainnya. 
Form untuk melakukan evaluasi teknis paket pekerjaan dapat dilihat pada Gambar 8 dibawah ini.

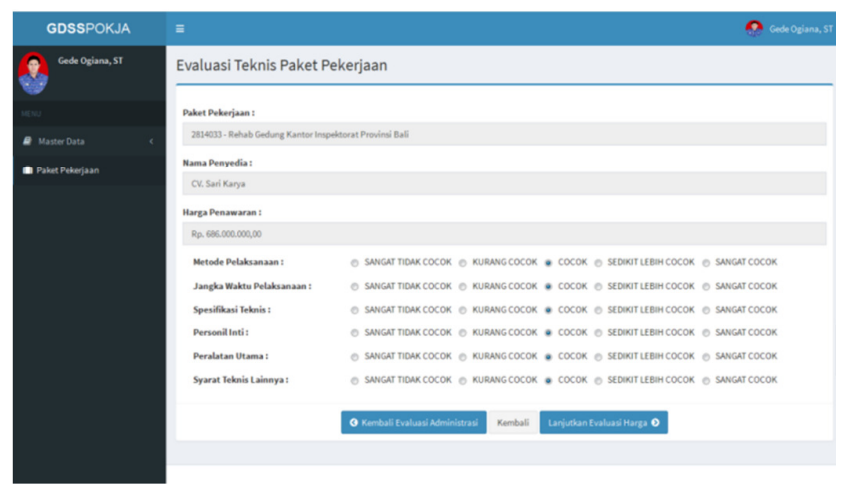

Gambar 8. Form Evaluasi Teknis

3. Evaluasi Harga Metode AHP

Proses penilaian kriteria harga dilakukan terhadap perusahaan yang sudah dievaluasi teknis. seperti yang terlihat pada form evaluasi harga paket pekerjaan pada Gambar 9. Evaluasi harga dilakukan dengan memberikan nilai sesuai subkriteria harga pada Tabel 1. Pada sistem ini dokumen harga yang dievaluasi adalah kecocokan total harga penawaran, harga satuan timpang, analisa harga, kewajaran harga dan syarat harga lainnya. Dengan telah melakukan evaluasi harga, maka evaluasi sudah selesai dilakukan. Selanjutnya dilanjutkan ke proses Borda secara otomatis, jika dalam hal ketujuh Pokja ULP sudah melakukan 3 tahap evaluasi pada Aplikasi GDSS.

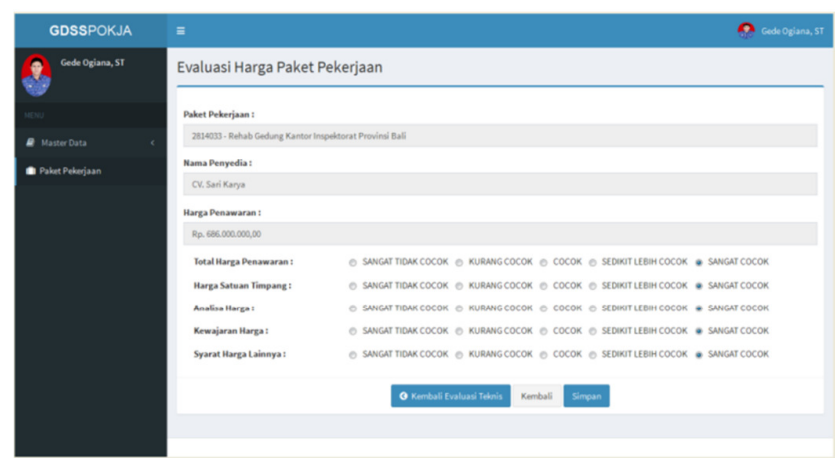

Gambar 9. Form Evaluasi Harga

\section{Hasil GDSS Evaluasi Penawaran Metode AHP}

Hasil evaluasi Pokja ULP selaku individual decision adalah berupa nilai dan peringkat oleh satu anggota Pokja ULP. Sebelum dikonfirmasi oleh Ketua Pokja ULP atau salah satu anggota Pokja ULP proses evaluasi baik administrasi, teknis dan harga, Pokja dapat mengubah atau mengedit penilaian apabila terjadi kekeliruan dalam penilaian dokumen penawaran. Atau terdapat penyedia yang mempunyai nilai dan rangking yang sama, maka proses evaluasi dapat diubah. Salah satu contoh penilaian oleh satu anggota Pokja ULP dapat dilihat pada Tabel 6 .

TABEL VI

CONTOH HASIl PENILAIAN AHP PER POKJA ULP

\begin{tabular}{|c|c|c|c|c|c|}
\hline \multirow{2}{*}{ Perusahaan } & \multicolumn{3}{|c|}{ Katagori } & \multirow{2}{*}{ Total } & \multirow{2}{*}{ Peringkat } \\
\cline { 2 - 4 } & Adm & Teknis & Harga & & 2 \\
\hline $\begin{array}{c}\text { CV. Sari } \\
\text { Karya }\end{array}$ & 0,42 & 0,08 & 0,01 & 0,51 & 2 \\
\hline $\begin{array}{c}\text { CV. Jaya } \\
\text { Karma }\end{array}$ & 0,10 & 0,13 & 0,03 & 0,26 & 3 \\
\hline $\begin{array}{c}\text { CV. Wija } \\
\text { Karya }\end{array}$ & 0,42 & 0,08 & 0,10 & $0, .60$ & 1 \\
\hline $\begin{array}{c}\text { CV. Santi } \\
\text { Graha }\end{array}$ & 0,10 & 0,02 & 0,06 & 0,18 & 4 \\
\hline
\end{tabular}

Sedangkan pada Tabel 7 dibawah ini merupakan hasil penilaian per anggota Pokja ULP.

TABEL VII

Hasil PENILAIAN AHP PER POKJA ULP

\begin{tabular}{|c|c|c|c|c|c|}
\hline \multirow{2}{*}{ Nama Pokja } & \multirow{2}{*}{ Penyedia } & \multicolumn{3}{|c|}{ Katagori } & \multirow{2}{*}{ Skor } \\
\hline & & $A d m$ & Teknis & Harga & \\
\hline $\begin{array}{c}\text { Dewa Gde } \\
\text { Putra } \\
\text { Parmana, ST }\end{array}$ & $\begin{array}{c}\text { CV. Sari } \\
\text { Karya }\end{array}$ & 0,309 & 0,152 & 0,072 & 0,533 \\
\hline $\begin{array}{c}\text { Gede } \\
\text { Ogiana, ST }\end{array}$ & $\begin{array}{c}\text { CV. Sari } \\
\text { Karya }\end{array}$ & 0,420 & 0,082 & 0,100 & 0,602 \\
\hline $\begin{array}{c}\text { Made Wijaya } \\
\text { Kusuma, ST }\end{array}$ & $\begin{array}{c}\text { CV. Sari } \\
\text { Karya }\end{array}$ & 0,361 & 0,185 & 0,093 & 0,639 \\
\hline $\begin{array}{c}\text { I G N Dwi } \\
\text { Suwariantha }\end{array}$ & $\begin{array}{c}\text { CV. Sari } \\
\text { Karya }\end{array}$ & 0,390 & 0,173 & 0,079 & 0,642 \\
\hline $\begin{array}{l}\text { Ir. I Nyoman } \\
\text { Wiarta, MT }\end{array}$ & $\begin{array}{c}\text { CV. Sari } \\
\text { Karya }\end{array}$ & 0,390 & 0,197 & 0,086 & 0,673 \\
\hline $\begin{array}{l}\text { Ni Nyoman } \\
\text { Trisnawati, } \\
\text { ST }\end{array}$ & $\begin{array}{c}\text { CV. Sari } \\
\text { Karya }\end{array}$ & 0,390 & 0,197 & 0,086 & 0,673 \\
\hline $\begin{array}{l}\text { Ir. I Made } \\
\text { Winarsa }\end{array}$ & $\begin{array}{c}\text { CV. Sari } \\
\text { Karya }\end{array}$ & 0,420 & 0,197 & 0,093 & 0,710 \\
\hline
\end{tabular}

\section{Hasil GDSS Proses Borda}

Hasil dari perangkingan calon pemenang menggunakan motode Borda merupakan hasil keputusan kelompok dalam proses evaluasi penawaran.

Setelah ketujuh Pokja ULP melakukan evaluasi terhadap semua peserta yang ikut dalam satu paket lelang pekerjaan konstruksi sebagaiman Tabel 7, maka selanjutnya secara otomatis nilai dari masing-masing anggota Pokja ULP tersebut digabungkan sesuai konsep metode Borda dengan hasil nilai dan peringkat yang dapat dilihat pada Tabel 8 . Peserta lelang yang mempunyai total skor paling tinggi dan rangking teratas dinyatakan sebagai pemenang lelang yang akan direkomendasikan dalam keputusan penentuan pemenang lelang dalam proses pemilihan penyedia konstruksi di ULP Pemerintah Provinsi Bali.

TABEL VIII

Hasil Evalusi Penawaran Dengan Metode Borda

\begin{tabular}{|c|c|c|c|c|c|c|}
\hline \multirow{2}{*}{ Penyedia } & \multicolumn{4}{|c|}{ Hasil Peringkat AHP } & \multirow{2}{*}{ Skor } & \multirow{2}{*}{ Peringkat } \\
\hline & 1 & 2 & 3 & 4 & & \\
\hline $\begin{array}{c}\text { CV. Sari } \\
\text { Karya }\end{array}$ & 7 & - & - & - & 21 & 1 \\
\hline $\begin{array}{c}\text { CV. Jaya } \\
\text { Karma }\end{array}$ & - & 7 & - & - & 14 & 2 \\
\hline $\begin{array}{l}\text { CV. Wija } \\
\text { Karya }\end{array}$ & - & - & 7 & - & 7 & 3 \\
\hline $\begin{array}{l}\text { CV. Santi } \\
\text { Graha }\end{array}$ & - & - & - & 7 & 0 & 4 \\
\hline $\begin{array}{c}\text { Bobot } \\
\text { Peringkat }\end{array}$ & 3 & 2 & 1 & 0 & & \\
\hline
\end{tabular}




\section{E. Perbandingan Sistem Gugur dan Sistem GDSS}

Perbandingan sistem gugur yang merupakan sistem evaluasi penawaran yang masih digunakan sampai saat ini dan sistem GDSS yang merupakan hasil penelitian menggunakan metode AHP dan Borda. Hal ini dilakukan guna mengetahui perbedaan kedua sistem tersebut. Perbandingan dilakukan dengan uji coba evaluasi terhadap 10 paket pekerjaan konstruksi yang sudah dilelang pada tahun anggaran 2015 dan membandingkan hasilnya.

Adapun perbedaan kedua sistem evaluasi penawaran tersebut dapat dijelaskan pada Tabel 9 .

TABEL IX

PERBEDAAN Sistem GUGUR DAN GDSS

\begin{tabular}{|c|c|c|}
\hline No & Sistem Gugur & GDSS \\
\hline 1 & $\begin{array}{l}\text { Proses pengolahan data } \\
\text { evaluasi masih menggunakan } \\
\text { spradsheet excel dan dalam } \\
\text { bentuk kertas sehingga } \\
\text { mengurangi efesiensi waktu. }\end{array}$ & $\begin{array}{l}\text { Menggunakan } \\
\text { MySQL yang mendukung } \\
\text { pengolahan data yang cepat } \\
\text { dan efektif baik dalam hal } \\
\text { penginputan maupun } \\
\text { penyimpanan data. }\end{array}$ \\
\hline 2 & $\begin{array}{l}\text { Lamban dalam pencarian data } \\
\text { karena masih harus membuka } \\
\text { semua tabel yang ada (sheet by } \\
\text { sheet). }\end{array}$ & $\begin{array}{l}\text { Pencarian data lebih efesien } \\
\text { tanpa harus membuka sheet } \\
\text { dan mencari data satu per } \\
\text { satu. }\end{array}$ \\
\hline 3 & $\begin{array}{l}\text { Pengambilan keputusan masih } \\
\text { bersifat individu, karena } 1 \\
\text { paket pekerjaan dievaluasi oleh } \\
1 \text { anggota Pokja sehingga } \\
\text { terkesan kurang optimal dan } \\
\text { tidak sesuai dengan ketentuan } \\
\text { yang seharusnya merupakan } \\
\text { keputusan kelompok. }\end{array}$ & $\begin{array}{l}\text { Meningkatkan sinkronisasi } \\
\text { anggota kelompok kerja dan } \\
\text { meningkatkan kualitas dalam } \\
\text { keputusan karena semua } \\
\text { anggota Pokja dapat } \\
\text { berpartisipasi secara optimal, } \\
\text { dan hasil keputusan adalah } \\
\text { keputusan kelompok. }\end{array}$ \\
\hline 4 & $\begin{array}{l}\text { Tingkat kelulusan cendrung } \\
\text { lebih rendah karena terdapat } \\
\text { penyedia yang gugur pada } \\
\text { suatu tahap evaluasi dan } \\
\text { evaluasi tidak dilanjutkan } \\
\text { terhadap peserta yang gugur } \\
\text { tersebut. }\end{array}$ & $\begin{array}{l}\text { Tingkat kelulusan cendrung } \\
\text { lebih tinggi karena semua } \\
\text { penyedia dievaluasi dan } \\
\text { dinyatakan lulus sesuai nilai } \\
\text { dan peringkat yang diperoleh. }\end{array}$ \\
\hline
\end{tabular}

Namun disisi lain kedua metode tersebut memiliki kesamaan, hal ini dapat disimpulkan dari hasil perbandingan yang dilakukan dalam penelitian ini, baik evaluasi sistem gugur dan GDSS evaluasi penawaran untuk rangking 1 dan 2 tetap pada posisinya.

\section{F. Pengujian Sistem}

Setelah tahap implementasi dilakukan maka dilanjutkan dengan pengujian aplikasi GDSS yang diperlukan untuk mengetahui apakah sistem telah siap untuk digunakan oleh pengguna [13]. Pengujian sistem yang digunakan untuk menguji fungsional dan kegunaan dari GDSS evaluasi penawaran adalah alpha dan beta.

1. Pengujian Alpha

Pengujian alpha dilakukan untuk mengetahui fungsional dari menu-menu yang tersedia pada aplikasi GDSS evaluasi penawaran berdasarkan rencana pengujian dengan menggunakan pendekatan black box testing [13].

Responden pada pengujian ini adalah 2 orang ahli dalam bidang layanan pengadaan (LPSE Provinsi Bali) dan 5 orang ahli dalam bidang bahasa yang memiliki kemampuan dalam mengevaluasi kinerja dan fungsional sistem (ITM Bali).

Gede Ogiana: Group Decision Support System (GDSS)...
Hasil pengujian black box tersebut adalah bahwa GDSS Evaluasi Penawaran secara fungsional 95,45 \% telah berjalan dengan baik dan dinyatakan valid.

2. Pengujian Alpha

Pengujian beta yang digunakan untuk menguji kegunaan dan penerimaan sesorang dari GDSS adalah usability testing [14][15]. Pengujian dilakukan dengan metode kuisioner dengan responden user yaitu 7 anggota Pokja ULP selaku pengguna yang mengerti proses evaluasi penawaran.

Usability testing dilakukan diruang Pokja Konstruksi ULP Pemerintah Provinsi Bali dengan menggunakan instrument berupa 7 buah komputer/laptop dan kuisioner.

Tahap awal, Pokja ULP diberikan task berupa tugas mengevaluasi penawaran menggunakan aplikasi GDSS.

Setelah Task dilakukan oleh Pokja, selanjutnya kuisioner yang berisi 10 pertanyaan untuk mendapatkan penilaian dari user yang dirasa cukup untuk mendapatkan penilaian dan pemahaman dari segi aspek usability [15]. Kuisioner dibuat dan dinilai dalam 5 skala nilai (model skala Likert) yang sudah digunakan dalam penelitian sebelumnya [15]. Berdasarkan hasil analisa berupa persentase jawaban kuisioner sebagai hasil dari usability testing yang dilakukan terhadap 7 responden, maka diperoleh rekap nilai usability sebagaimana Tabel 10 .

TABEL X

REKAP NILAI USABILITY

\begin{tabular}{|l|l|l|}
\hline No. & \multicolumn{1}{|c|}{ Attribut } & Nilai \\
\hline 1 & Kemudahan interface dikenali & 4.00 \\
\hline 2 & $\begin{array}{l}\text { Kemudahan dalam mencari infromasi GDSS Evaluasi } \\
\text { Penawaran }\end{array}$ & 4.14 \\
\hline 3 & $\begin{array}{l}\text { Kemudahan melakukan proses penilaian GDSS } \\
\text { Evaluasi Penawaran }\end{array}$ & 4.00 \\
\hline 4 & $\begin{array}{l}\text { Kemudahan hasil penentuan calon pemenang } \\
\text { penyedia pekerjaan konstruksi }\end{array}$ & 3.71 \\
\hline 5 & $\begin{array}{l}\text { Kemudahan huruf pada sistem dibaca } \\
\text { Kemudahan simbol-simbol dipahami }\end{array}$ & 4.00 \\
\hline 7 & Desain warna yang nyaman & 3.57 \\
\hline 8 & Kemudahan Bahasa pada sistem dimengerti & 3.71 \\
\hline 9 & Kemudahann mendapatkan informasi setiap halaman & 4.00 \\
\hline 10 & $\begin{array}{l}\text { Kemudahan mengingat kembali menu-menu dan } \\
\text { tampilan sistem }\end{array}$ & 4.29 \\
\hline
\end{tabular}

Pada Tabel 10 merupakan hasil nilai penerimaan usability oleh pengguna yang menunjukkan bahwa aplikasi GDSS evaluasi penawaran memiliki tingkat usability yang baik karena nilai rata-rata berdasarkan pengukuran skala Likert 1 sampai dengan 5 berada diatas 3 .

\section{KESIMPULAN}

Kesimpulan yang dapat ditarik dari penelitian ini adalah sebagai berikut :

1. GDSS yang dirancang untuk evaluasi penawaran pekerjaan konstruksi di Pokja ULP Pemerintah Provinsi Bali berhasil dibuat dengan menerapkan metode AHP dan Borda. Hasil GDSS evaluasi penawaran ini memberikan

p-ISSN:1693 - 2951; e-ISSN: 2503-2372

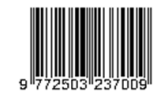


solusi pengolahan dan penyimpanan data menjadi lebih cepat dan waktu untuk evaluasi lebih efesien dibandingkan sistem gugur. Meningkatkan kualitas Pokja ULP sebagai keputusan kelompok.

2. Sesuai hasil pengujian GDSS evaluasi penawaran dengan metode black box diketahui bahwa fungsionalitas aplikasi GDSS yang dibuat $95,45 \%$ dapat berjalan sesuai dengan yang diharapkan dan dinyatakan valid. Usability testing juga menunjukkan sistem pendukung keputusan kelompok kerja ULP yang telah dibuat telah memiliki nilai Usability yang baik.

\section{REFERENSI}

[1] I P. A. Eka D.U dan Nyoman Putra Sastra, "Perbandingan Performansi Pengamanan File Backup LPSE Menggunakan Algoritma DES dan AES " Majalah Ilmiah Teknologi Elektro, vol. 15, no. 01, pp.111-117, Januari-Juni 2016

[2] "Peraturan Presiden Nomor 4 Tahun 2015, " tentang Perubahan Keempat atas Peraturan Presiden Nomor 54 Tahun 2010 tentang Pengadaan Barang/Jasa Pemerintah, Januari 2015.

[3] I Made Aryawan, Linawati dan I.A. Dwi Giriantari , "Virtualisasi Layanan Pengadaan Secara Elektronik Pemerintah Kabupaten Badung Menggunakan Metode Blue Ocean Strategy dan Balanced Scorecard ," Majalah Ilmiah Teknologi Elektro, vol. 15, no. 2, pp.13-20, JuliDesember 2016.

[4] Dwini Meidelfi dan Sri Hartati , "Aplikasi Sistem Pendukung Keputusan Kelompok untuk Pemilihan Tanaman Pertanian Lahan Kering," Berkala MIPA, 23(3),pp.236-246, September 2013.

[5] Bhakti Susilo dan Azhari SN, "GDSS Penentuan Lokasi Shelter Baru Transjogja Menggunakan Metode Brown-Gibson dan Borda," IJCCS, vol. 6, no. 2, pp.57-66, July 2012.

[6] Mutammimul Ula dan Azhari SN, "Sistem Pendukung Keputusan Kelompok Penentuan Kelayakan Lokasi Pemukiman," Indonesia Journal of Computing and Cybernetics System (IJCCS), vol. 7, no. 1, 2013.

[7] Renny Puspita Sari, Alb.Joko Santoso dan Ernawati "Perancangan Sistem Pendukung Keputusan Kelompok Metode Topsis dan Borda untuk Evaluasi Kegiatan Penanganan Infrastruktur Jalan ," Jurnal Media Infotama, vol. 10, no. 2, pp.110-119, September 2014.

[8] Standy Oei, "Group Decisin Support System Untuk Pembelian Rumah Dengan Menggunakan Analytic Hirarchy Process (AHP) dan Borda", Seminar Nasional Informatika 2013 (semnasIF2013), UPN Veteran Yogyakarta. ISSN : 1979-2328 D-66 - D73, 18 Mei 2013.

[9] Sri Wahyuni Priyanti, Indah Fitri Astuti dan Dina Marisa Khairina ,"Penerapan Multifacktor Evaluation Process (Mfep) Untuk Pemilihan Kontraktor Pada Proyek Seminisasi Jalan (Studi Kasus : Unit Layanan Pengadaan Kabupaten Kutai Kartanegara), " Prosiding Seminar Sains dan Teknologi FMIPA Unmul, ISBN: 978-602-72658-1-3, pp.456-460, Maret 2016.

[10] Peggi Sri Astuti dan Retantyo Wardoyo "'Sistem Pendukung Keputusan Penentuan Pemenang Tender Pekerjaan Konstruksi dengan Metode Fuzzy AHP ," IJCCS, vol. 8, no. 1, pp.1-12, Januari 2014.

[11] Abdussalam Al Akbar, Sapri dan Leni Natalia Zulita,"Sistem Pendukung Keputusan Penentuan Penyaluran Beras Bersubsidi Menggunakan Metode Analytic Hirarchy Process (AHP)", Seminar Nasional Informatika 2013 (semnasIF2013), UPN Veteran Yogyakarta. ISSN : 1979-2328 D-66 - D73, 18 Mei 2013.

[12] Gunawan, Fandi Halim dan Wilson "Penerapan Metode Topsis dan AHP Pada Sistem Penunjang Keputusan Penerimaan Anggota Baru, Studi Kasus : Ikatan Mahasiswa Sistem Informasi STMIK Mikroskil Medan ," JSM STIMIK Mikroskil, vol. 15, no. 2, pp.101-110, Oktober 2014.

[13] Made Pradnyana Ambara, Made Sudarma dan I Nyoman Satya Kumara "Perbandingan Performansi Pengamanan File Backup LPSE Menggunakan Algoritma DES dan AES ," Majalah Ilmiah Teknologi Elektro, vol. 15, no. 01, pp.1-8, Januari-Jun 2016.

[14] Ardiansyah dan Muhammad Imam Ghazali ,"Pengujian Usability User Interface dan User Experience Aplikasi E-Reader Skripsi Berbasis Hypertext ," Jurnal Ilmiah Teknologi Informasi Terapan, vol. II, no. 3, pp.213-220, 15 Agustus 2016.

[15] Theresia Wuri Oktaviani "Perancangan User Interface Berbasis Web untuk Home Automation Gateway Berbasis IQRF TR53B , JNTETI, vol. 03, no. 03, pp.179-186, Agustus 2014. 